\title{
Modeling nitrate from land surface to wells' perforations under agricultural land: success, failure, and future scenarios in a Mediterranean case study
}

\author{
Yehuda Levy $^{1}$, Roi H. Shapira ${ }^{2}$, Benny Chefetz ${ }^{3}$, and Daniel Kurtzman ${ }^{4}$ \\ ${ }^{1}$ Hydrology and Water Resources Program, The Hebrew University of Jerusalem, The Edmond J. Safra \\ Campus - Givat Ram, 9190401 Jerusalem, Israel \\ ${ }^{2}$ Mekorot, Israel National Water Company, Lincoln 9, 6713402 Tel Aviv, Israel \\ ${ }^{3}$ Department of Soil and Water Sciences, Faculty of Agriculture, Food and Environment, \\ The Hebrew University of Jerusalem, 7610001 Rehovot, Israel \\ ${ }^{4}$ Institute of Soil, Water and Environmental Sciences, Volcani Center, Agricultural Research Organization, \\ HaMaccabim Road 68, 7505101 Rishon LeZion, Israel \\ Correspondence to: Yehuda Levy (yehuda.levy1@mail.huji.ac.il)
}

Received: 2 February 2017 - Discussion started: 20 February 2017

Revised: 21 June 2017 - Accepted: 23 June 2017 - Published: 26 July 2017

\begin{abstract}
Contamination of groundwater resources by nitrate leaching under agricultural land is probably the most troublesome agriculture-related water contamination worldwide. Contaminated areas often show large spatial variability of nitrate concentration in wells. In this study, we tried to assess whether this spatial variability can be characterized on the basis of land use and standard agricultural practices. Deep soil sampling $(10 \mathrm{~m})$ was used to calibrate vertical flow and nitrogen-transport numerical models of the unsaturated zone under different agricultural land uses. Vegetable fields (potato and strawberry) and deciduous orchards (persimmon) in the Sharon area overlying the coastal aquifer of Israel were examined. Average nitrate-nitrogen fluxes below vegetable fields were $210-290 \mathrm{~kg} \mathrm{ha}^{-1} \mathrm{yr}^{-1}$ and under deciduous orchards were $110-140 \mathrm{~kg} \mathrm{ha}^{-1} \mathrm{yr}^{-1}$. The output water and nitrate-nitrogen fluxes of the unsaturated-zone models were used as input data for a three-dimensional flow and nitratetransport model in the aquifer under an area of $13.3 \mathrm{~km}^{2}$ of agricultural land. The area was subdivided into four agricultural land uses: vegetables, deciduous orchards, citrus orchards, and non-cultivated. Fluxes of water and nitratenitrogen below citrus orchards were taken from a previous study in the area. The groundwater flow model was calibrated to well heads by changing the hydraulic conductivity. The nitrate-transport model, which was fed by the above-
\end{abstract}

mentioned models of the unsaturated zone, succeeded in reconstructing the average nitrate concentration in the wells. However, this transport model failed in calculating the high concentrations in the most contaminated wells and the large spatial variability of nitrate concentrations in the aquifer. To reconstruct the spatial variability and enable predictions, nitrate fluxes from the unsaturated zone were multiplied by local multipliers. This action was rationalized by the fact that the high concentrations in some wells cannot be explained by regular agricultural activity and are probably due to malfunctions in the well area. Prediction of the nitrate concentration 40 years in the future with three nitrogen-fertilization scenarios showed that (i) under the "business as usual" fertilization scenario, the nitrate concentration (as $\mathrm{NO}_{3}^{-}$) will increase on average by $19 \mathrm{mg} \mathrm{L}^{-1}$; (ii) under a scenario of $25 \%$ reduction of nitrogen fertilization, the nitrate concentration in the aquifer will stabilize; (iii) with a $50 \%$ reduction of nitrogen fertilization, the nitrate concentration will decrease on average by $18 \mathrm{mg} \mathrm{L}^{-1}$. 


\section{Introduction}

\subsection{Groundwater contamination by nitrate under agricultural land}

Since the development of the Haber-Bosch process in 1910, in which ammonia $\left(\mathrm{NH}_{3}\right)$ is cheaply produced from atmospheric nitrogen $\left(\mathrm{N}_{2}\right)$, mineral nitrogen has become the most important and common fertilizer in modern intensive agriculture. This process earned Fritz Haber the Nobel Prize for chemistry in 1918 and its significance was emphasized for many decades thereafter (e.g., "the most important invention of the 20th century" - Smil, 1999; Erisman et al., 2008). However, nitrogen fertilization is commonly applied in surplus and leaches below the roots, mainly as the conservative anion nitrate $\left(\mathrm{NO}_{3}^{-}\right)$, which has strict limits under drinkingwater standards worldwide. As a consequence, nitrate has become the most common groundwater contamination caused by agricultural activity in many countries (Jalali, 2005; Vitousek et al., 2009; Burow et al., 2010; Kourakos et al., 2012; Yue et al., 2014; Wheeler et al., 2015; Wang et al., 2016). In Israel, for example, more than half of all the wells that have been disqualified as sources of drinking water were disqualified due to nitrate contamination (Israel Water Authority; IWA, 2015a). The process of groundwater contamination by nitrate occurs mainly below light soils and less under cultivated clays (Spalding and Exner, 1993; Kurtzman et al., 2016).

\subsection{The path from nitrogen fertilizer to nitrate in groundwater}

Many studies have reported leaching ranges of $25-90 \%$ of the nitrogen applied to agricultural fields in different crops and countries (Guimerá et al., 1995; McMahon and Woodside, 1997; Neilsen and Neilsen, 2002; Kraft and Stites, 2003; de Paz and Ramos, 2004; Ju et al., 2006; Zhao et al., 2011; Venterea et al., 2011). In Israel, Bar-Yosef et al. (1999) reported nitrate leaching of 55-65\% for different vegetables and field crops (18 crop varieties) in a 35-year survey. More recently, Turkeltaub et al. (2015) calculated leaching ratios in the range of $15-35 \%$ under a modern greenhouse for intensive growing of vegetables.

Applications of nitrogen fertilizers of different species, including nitrate, ammonium $\left(\mathrm{NH}_{4}^{+}\right)$, or organic nitrogen (e.g., urea, manure, compost) or a combination of these, are practiced. Most crops uptake only the mineral species (nitrate, ammonium). The nitrate and ammonium are uptaken by plant roots mostly in a mass transport process (advective and diffusive), which is limited by a crop-specific threshold concentration (Sorgona et al., 2006; Kurtzman et al., 2013). Some of the organic nitrogen in the soil is mineralized to ammonium, and in aerated light soils most of the ammonium is oxidized to nitrate (nitrification) in a relatively thin layer in the upper part of the soil column $(0-45 \mathrm{~cm}$; Kurtzman et al.,
2013). Moreover, ammonium is a cation and tends to adsorb to the soil solids (clay fraction, organic matter). Under anaerobic conditions, the nitrate is reduced to nitrogen gas via denitrification, which takes the nitrogen out of the system (Galloway et al., 2004). Nevertheless, denitrification is not a significant process in relatively aerated sandy soils and is frequently assumed to be negligible (Hanson et al., 2006; Doltra and Muñoz, 2010; Turkeltaub et al., 2015). Due to these processes, the nitrogen species that leaches down to the aquifer is mainly nitrate. In the groundwater, nitrate is diluted and transported mostly as a conservative anion that is often extracted out of the system by pumping wells. Denitrification in aquifers is an important process in some cases (e.g., Liao et al., 2012; Thayalakumaran et al., 2015; Green et al., 2016). Nevertheless, in the thick aquifer discussed here, dominated by sandy sediments and under Mediterranean climate, denitrification is negligible in the upper $95 \%$ of the aquifer's depth (Kurtzman et al., 2012). In environments that are more humid accesses, nitrogen from agricultural sources in surface water bodies is an ecological concern; however, under Mediterranean climate, the problem of groundwater contamination is the major problem concerning $N$ leaching from agricultural land.

Nitrate contamination of the groundwater below agricultural land is often characterized by significant spatial variability of the nitrate concentrations in wells (Hu et al., 2005; Liu et al., 2005; Wheeler et al., 2015). This variability may evolve from the spatial variability of the soil properties. Nevertheless, in an area with relatively uniform soil, it is most likely related to variable land use (crops) and inconsistent agricultural practices (Almasri and Kaluarachchi, 2007; Bian et al., 2016).

Research of nitrate leaching from agricultural land can be divided into three scales and zones of interest. Agricultural aspects of root uptake of nitrate and its seepage below the root zone have been studied quite extensively in the agricultural research domain, where transient mechanistic models are often used for the analysis (e.g., Hanson et al., 2006; Doltra and Muñoz, 2010). The developing vadose-zone hydrology discipline looks at nitrate data and processes deeper in the unsaturated zone as well (Kurtzman et al., 2013; Dahan et al., 2014). Regional assessments of groundwater contamination with nitrate make use of varying degrees of simplification of vadose-zone processes (e.g., Mercado, 1976; de Paz and Ramos, 2004; Kourakos et al., 2012).

The objective of this research was to quantitatively assess the nitrate throughout its course from fertilization on the field surface through the flow processes in the root zone, down through the thick unsaturated zone, and in the aquifer toward the pumping wells. We further aimed at reconstructing the observed groundwater nitrate concentrations by calculated fluxes from the unsaturated zone and at explaining the spatial variability of the nitrate concentration in the groundwater by the spatial variability of the surface land use. Finally, we used the field- and regional-scale calibrated models for future 


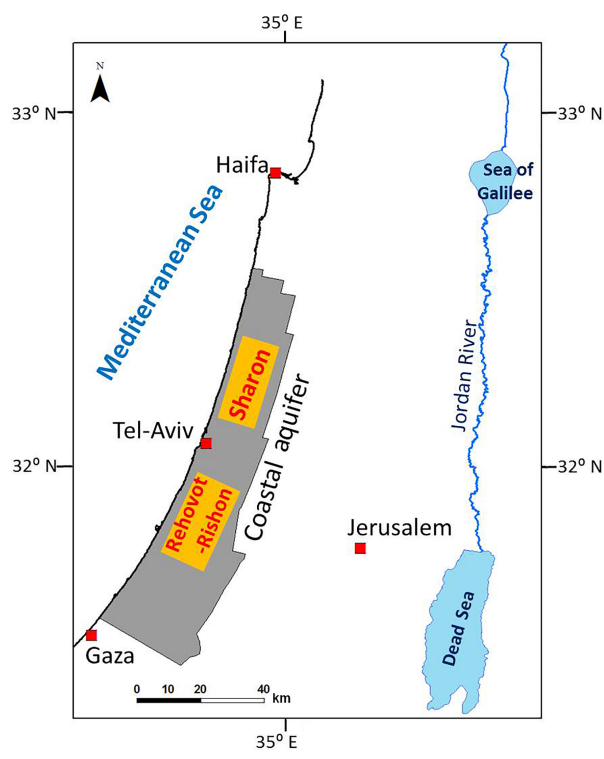

Figure 1. Location map of the Israeli coastal aquifer and two areas (in red) with major nitrate contamination of the groundwater. This work presents a case study focusing on the Sharon area.

assessment of aquifer contamination under different fertilization scenarios.

\section{Materials and methods}

\subsection{Research area: nitrate contamination in the Sharon area, Israel}

The nitrate problem in groundwater in Israel is concentrated under intensively cultivated areas of Mediterranean red sandy-loam (Hamra) soil overlying the coastal aquifer (IWA, 2015b; Kurtzman et al., 2016). Two main regions in which nitrate contamination has been a concern for several decades are Rehovot-Rishon (Mercado, 1976) and the Sharon region (Kurtzman et al., 2013). This research focuses on the Sharon area (Fig. 1). The Israeli coastal aquifer is an unconfined aquifer, one of the most important freshwater sources in Israel for both agriculture and domestic consumption.

The climate is semi-arid with annual precipitation of $550 \mathrm{~mm}$ mainly during the winter season from November to April. The main land uses over the aquifer are agricultural and residential (cities, towns, and villages). The aquifer is in the Kurkar group (Pleistocene) composed of sands, calcareous sandstone, and marine and continental silty and clay lenses. The aquifer lies over the thick clays of the Saqiye group, which are conceptualized as an aquiclude (Gvirtzman, 2002). The unsaturated-zone thickness ranges from 3 to $80 \mathrm{~m}$ below ground surface.

This research concentrates on a $13.3 \mathrm{~km}^{2}$ agricultural area in the Sharon region. Nitrate concentration in wells in this research area has been increasing by an average $1 \mathrm{mg} \mathrm{L}^{-1} \mathrm{yr}^{-1}$

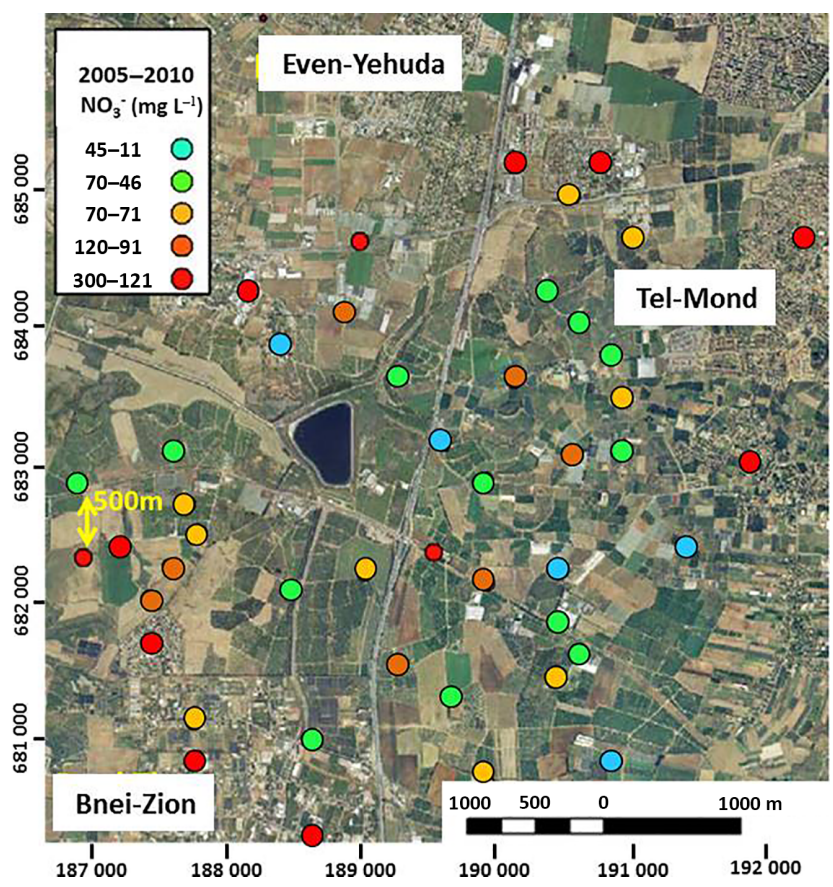

Figure 2. The agricultural area selected for modeling and 5-year average nitrate concentration in wells. Note the high spatial variability. Nitrate concentration data are from the Israel Water Authority. Coordinates system: Israeli Transverse Mercator (ITM).

for more than 40 years (Kurtzman et al., 2013). Although generally considered contaminated, significant spatial variability exists in the nitrate concentration in wells over short distances. Heavily contaminated wells can be at as little as $500 \mathrm{~m}$ from a non-contaminated well (Fig. 2).

The coefficient of variation (standard deviation per average) of nitrate concentration in the wells in Fig. 2 is $38 \%$ (Levy, 2015). This spatial variability indicates local contamination sources rather than regional contamination. It might evolve from crop type, fertilization masses, or the agricultural practice in the fields at ground surface. Therefore, the research area was divided into four characteristic land uses: vegetables ( $40 \%$ of area, large masses of nitrogen fertilization), citrus (33\% of area, also transpiring in the winter season), deciduous (14\% of area, large volumes of irrigation), and no crop (13\% of area) (land-use data from Survey of Israel maps, 2000).

\subsection{Nitrate fluxes from the fields to the deep unsaturated zone}

\subsubsection{Fields, irrigation, fertilization, and meteorological data}

For the three aforementioned crop types, representative fields were selected for deep sampling in the Hamra soils of the Sharon region: potato and strawberry fields representing the vegetable land use; a persimmon plantation representing the 
deciduous crop, and data from an orange orchard reported in Kurtzman et al. (2013) representing citrus. In each field, data of irrigation and fertilization regimes (quantities and timing in daily resolutions) were collected from the farmers. Data on irrigation water quality (nitrate and chloride concentrations) were collected from the Israel Water Authority. The potato field was irrigated by sprinklers, with an average irrigation depth of $480 \mathrm{~mm} \mathrm{yr}^{-1}$, and fertilized with $450 \mathrm{~kg} \mathrm{~N} \mathrm{ha}^{-1} \mathrm{yr}^{-1}$. The strawberry field was irrigated by micro-sprinklers (at the early stage of growing) and drip irrigation afterwards to an average depth of $1000 \mathrm{~mm} \mathrm{yr}^{-1}$ and fertilized with $450 \mathrm{~kg} \mathrm{Nha}^{-1} \mathrm{yr}^{-1}$. Strawberries were grown under plastic tunnels and the field was completely covered with a plastic sheet during the winter; hence, precipitation was not counted in the water balance for this field. The persimmon orchard was irrigated by micro-sprinklers to an average depth of $850 \mathrm{~mm} \mathrm{yr}^{-1}$, and fertilized with $200 \mathrm{~kg} \mathrm{Nha}^{-1} \mathrm{yr}^{-1}$. The nitrogen forms of the applied fertilization were ammonium-nitrate solution in the irrigation water (persimmon and strawberry) and dry scattering of urea (potato). Nitrogen in the compost was accounted for in the strawberry and potato fields where this organic amendment was applied. The farmers in all representative fields reported that the same crop was cultivated for at least 15 years before sampling (with minor exceptions for the potato field). Time series of daily precipitation and reference evapotranspiration (Penman-Monteith equation; Allen et al., 1998) for each field were collected from nearby automated meteorological stations operated by the Israel Ministry of Agriculture.

\subsubsection{Field sampling and soil analysis}

In each of the three fields (persimmon, strawberry, and potato), three sampling core holes were drilled using the direct push technique, and a continuous core was obtained from 0 to $10 \mathrm{~m}$ depth (Fig. 3). The core holes were drilled at a distance of 50-200 m from each other. Soil (and sediment) cores were cut into $30 \mathrm{~cm}$ segments. Drilling was done in June 2012. Core segments were sealed with caps and tape and kept in a cooler until reaching the laboratory, where the core segments were analyzed for the following variables: gravimetric water content $\left(105^{\circ} \mathrm{C}\right)$, bulk density (core dry mass per volume), gravimetric particle-size distribution (hydrometer method), chloride concentration of a 1:2 soil-to-water extract (with Sherwood 926 chloridometer), nitrate and ammonium concentrations in a $1 \mathrm{M} \mathrm{KCl} 1: 5$ soil-to-water solution extract (Kachurina et al., 2000, with QuikChem 8000 autoanalyzer, Lachat Instruments, Loveland, CO). The soil samples that were used for extraction were ground and sieved to $2 \mathrm{~mm}$ after drying $\left(40^{\circ} \mathrm{C}\right.$ for 3 days).

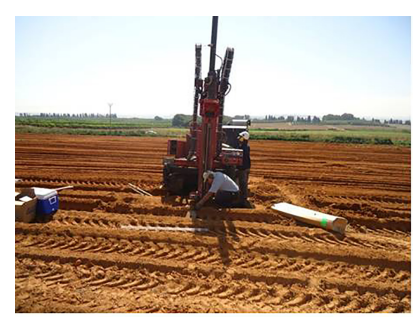

(a) Potato

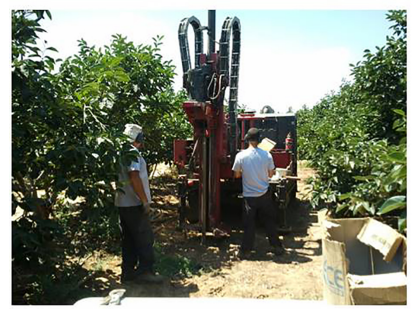

(c) Persimmon

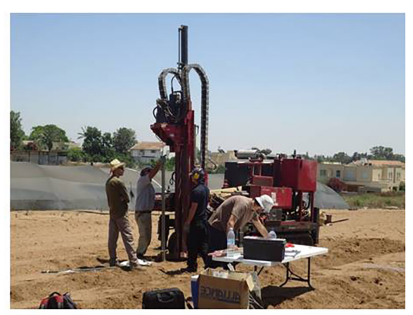

(b) Strawberry

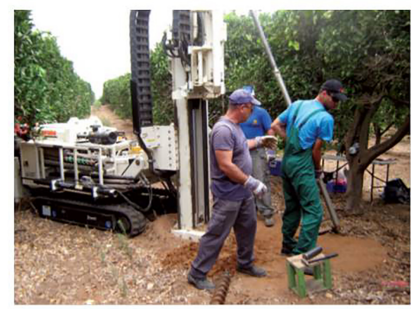

(d) Citrus
Figure 3. Direct push sampling of the unsaturated zone $(0-10 \mathrm{~m}$ below ground surface) under the different agricultural land uses. Panels (a-c) show what was sampled in the current study. Panels (d) show what was sampled for Kurtzman et al. (2013); the unsaturated model developed there was used here.

\subsubsection{Modeling water flow and nitrogen transport in the unsaturated zone}

\section{Steady-state approximations}

Average fluxes of water and nitrate-nitrogen toward the groundwater under the fields were calculated in a steady-state approximation with the chloride mass balance (Allison and Hughes, 1983; Scanlon et al., 2007):

$R=\frac{\left(P \cdot \mathrm{Cl}_{\mathrm{P}}+I \cdot \mathrm{Cl}_{I}\right) \int_{z=10 \mathrm{~m}}^{z=2 \mathrm{~m}} \theta(z) \mathrm{d} z}{\int_{z=10 \mathrm{~m}}^{z=2 \mathrm{~m}} \theta(z) \cdot \mathrm{Cl}_{\mathrm{PW}}(z) \mathrm{d} z}$,

where $R\left(\mathrm{LT}^{-1}\right)$ is the mean annual groundwater recharge flux, $P\left(\mathrm{~L} \mathrm{~T}^{-1}\right)$ is the mean annual precipitation flux, $I$ $\left(\mathrm{L} \mathrm{T}^{-1}\right)$ is the mean annual irrigation application, $\mathrm{Cl}\left(\mathrm{ML}^{-3}\right)$ is the steady-state approximation of the chloride concentration with subscripts $P, I$, and PW referring to precipitation, irrigation water, and unsaturated-zone pore water, respectively, and $\theta\left(\mathrm{L}^{3} \mathrm{~L}^{-3}\right)$ is the volumetric water content. The interval of integration for calculating deep unsaturatedzone averages was from $z=2 \mathrm{~m}$ (below the root zone) to $z=10 \mathrm{~m}$ depth (deepest available data). The steady-state approximation of nitrate flux to the groundwater was obtained by multiplying the water flux $(R$, Eq. 1$)$ by the depth- and $\theta$-weighted average of nitrate-nitrogen concentrations below the root zone:

$F_{\mathrm{NO}_{3}}=\frac{R \int_{z=10 \mathrm{~m}}^{z=2 \mathrm{~m}} \theta(z) \cdot \mathrm{NO}_{3}-N_{\mathrm{PW}}(z) \mathrm{d} z}{\int_{z=10 \mathrm{~m}}^{z=2 \mathrm{~m}} \theta(z) \mathrm{d} z}$, 
where $F_{\mathrm{NO}_{3}}\left(\mathrm{ML}^{-2} \mathrm{~T}^{-1}\right)$ is the mean annual flux of nitratenitrogen to the groundwater and $\mathrm{NO}_{3}-\mathrm{N}_{\mathrm{PW}}\left(\mathrm{ML}^{-3}\right)$ is the nitrate-nitrogen concentration in the deep vadose-zone pore water.

\section{Transient models}

Transient vertical 1-D numerical models of water flow and nitrogen transport were calibrated to data of one drill hole in each field: potato, strawberry, and persimmon. The numerical code HYDRUS-1D was used for the calibration and simulations (Šimůnek et al., 2009). The 1-D vertical Richards equation with a root water-uptake sink was used for modeling flow in the unsaturated zone:

$$
\frac{\partial \theta(h)}{\partial t}=\frac{\partial}{\partial z}\left[K(h) \cdot\left(\frac{\partial h}{\partial z}+1\right)\right]-S(h),
$$

where $t(\mathrm{~T})$ is the time, $z(\mathrm{~L})$ is the vertical coordinate, $h=$ $h(z, t)(\mathrm{L})$ is the pressure head, $\theta(\mathrm{h})$ is the volumetric water content, $K(h)\left(\mathrm{L} \mathrm{T}^{-1}\right)$ is the unsaturated hydraulic conductivity, and $S(h)\left(\mathrm{T}^{-1}\right)$ is a root water-uptake sink term which is non-zero in a transpiring root zone. The van GenuchtenMualem model (Mualem, 1976; van Genuchten, 1980) was used for the $\theta(h)$ and $K(h)$ relationships of the different sediment layers, and Feddes et al.'s (1978) functions, fitted to each crop, were used for $S(h)$ (Šimůnek et al., 2009).

One dimensional advection-dispersion equations representing chain reactions of the nitrogen system are presented in Eqs. (4-6). Only ammonium is accounted for in the solid phase. Sink/source terms for root uptake of ammonium and nitrate, urea/compost mineralization, ammonium volatilization, ammonium nitrification, and nitrate denitrification complete the right-hand side of this equation system.

$$
\begin{aligned}
& \frac{\partial \theta C_{\mathrm{Ur}}}{\partial t}=\frac{\partial}{\partial z}\left(\theta D \frac{\partial C_{\mathrm{Ur}}}{\partial z}\right)-\frac{\partial q C_{\mathrm{Ur}}}{\partial z}-\mu_{\mathrm{min}} \theta C_{\mathrm{Ur}}, \\
& \frac{\partial \theta C_{\mathrm{NH}_{4}}}{\partial t}+\frac{\partial \rho K_{d} C_{\mathrm{NH}_{4}}}{\partial t}=\frac{\partial}{\partial z}\left(\theta D \frac{\partial C_{\mathrm{NH}_{4}}}{\partial z}\right)-\frac{\partial q C_{\mathrm{NH}_{4}}}{\partial z} \\
& \quad-f_{\mathrm{NH}_{4}} S C_{\mathrm{NH}_{4}}+\mu_{\mathrm{min}} \theta C_{\mathrm{Ur}}-\mu_{\mathrm{nit}} \theta C_{\mathrm{NH}_{4}}-\mu_{\mathrm{vol}} \theta C_{\mathrm{NH}_{4}}, \\
& \frac{\partial \theta C_{\mathrm{NO}_{3}}}{\partial t}=\frac{\partial}{\partial z}\left(\theta D \frac{\partial C_{\mathrm{NO}_{3}}}{\partial z}\right)-\frac{\partial q C_{\mathrm{NO}_{3}}}{\partial z}-f_{\mathrm{NO}_{3}} S \cdot C_{\mathrm{NO}_{3}} \\
& \quad+\mu_{\mathrm{nit}} \theta C_{\mathrm{NH}_{4}}-\mu_{\mathrm{dnit}} \theta C_{\mathrm{NO}_{3}},
\end{aligned}
$$

where $C_{\mathrm{Ur}}, C_{\mathrm{NH}_{4}}$, and $C_{\mathrm{NO}_{3}}\left(\mathrm{ML}^{-3}\right)$ are concentrations of the nitrogen species (urea, ammonium, and nitrate, respectively) in the porewater solution, $\rho\left(\mathrm{ML}^{-3}\right)$ is the soil's bulk density, $\theta\left(\mathrm{L}^{3} \mathrm{~L}^{-3}\right)$ is volumetric water content, $D\left(\mathrm{~L}^{2} \mathrm{~T}^{-1}\right)$ is the hydrodynamic dispersion coefficient, $q\left(\mathrm{~L} \mathrm{~T}^{-1}\right)$ is the water flux, $f_{\mathrm{NH}_{4}} \mathrm{SC}_{\mathrm{NH}_{4}}$ and $f_{\mathrm{NO}_{3}} \mathrm{SC}_{\mathrm{NO}_{3}}\left(\mathrm{M} \mathrm{T}^{-1} \mathrm{~L}^{-3}\right)$ are the root ammonium-nitrogen- and nitrate-nitrogen-uptake sinks, respectively, where $f_{\mathrm{NH}_{4}}$ and $f_{\mathrm{NO}_{3}}$ are user-defined functions relating solute uptake to the water uptake $S$ and solute concentrations; $\mu_{\min }\left(\mathrm{T}^{-1}\right)$ is a first-order urea/compost mineralization rate (sink term in Eq. 4 and source term in
Eq. 5), $\mu_{\text {nit }}\left(\mathrm{T}^{-1}\right)$ is a first-order nitrification rate (sink term in Eq. 5 and source term in Eq. 6), $\mu_{\mathrm{vol}}\left(\mathrm{T}^{-1}\right)$ is a first-order ammonium-nitrogen volatilization rate, $\mu_{\text {dnit }}\left(\mathrm{T}^{-1}\right)$ is a firstorder denitrification rate, and $k_{\mathrm{d}}\left(\mathrm{L}^{3} \mathrm{M}^{-1}\right)$ is the ammoniumnitrogen partition coefficient. Application of compost (strawberry) was treated with Eqs. (4-6) as follows: farmers' reports of annual application of compost $\left(\mathrm{m}^{3} \mathrm{ha}^{-1}\right)$ were converted to mineralized nitrogen (Eq. 4) according to 15 and $5 \%$ nitrogen by mass mineralized in the first and second years after application, respectively (Eghball et al., 2002). A dry compost density of $600 \mathrm{~kg} \mathrm{~m}^{-3}$ with $2 \%$ of the dry mass consisting of nitrogen was used (Ben Hagai et al., 2011).

A total of 50 years (1962-2012) of daily precipitation, reference evapotranspiration (approximated from pan evaporation before 2002), irrigation water (with appropriate chloride and nitrate concentrations), and nitrogen fertilization was set as the upper boundary condition. A "free drainage" boundary (pressure gradient of 0 ) was used as the bottom boundary condition throughout. The calibration was aimed at fitting the measured profiles on the day of sampling, which was the last day of the 50 years of model runs, under the assumption of steady crop and the same agricultural practice during the 50 years.

Rosetta pedotransfer functions (Schaap et al., 2001) were used with particle-size distribution and bulk-density data to obtain initial values of the parameters of the hydraulic function $\theta(h)$ and $K(h)$ for the model layers in the top $10 \mathrm{~m}$ (which were sampled and analyzed). These initial values were slightly changed (i.e., only $K_{\mathrm{S}}$ within the same order of magnitude) during the calibration of the flow model in which the error between measured and modeled water contents was minimized. Dispersion coefficients of the soil/sediment layers were calibrated in the transport models with the unsaturated-zone chloride observations. Nitratenitrogen data were used for calibrating the nitrate, mostly by changing the function of nitrate uptake, $f_{\mathrm{NO}_{3}}$ (Eq. 6). All calibrations were performed manually by trial-and-error runs.

To account for the actual unsaturated-zone thickness in each cell of the groundwater model, the unsaturated models were extended/shortened to fit steady-state approximations of the actual unsaturated thickness $(4-50 \mathrm{~m}$ below the ground, at $1 \mathrm{~m}$ resolution; Fig. 4). This extension was also applied to the citrus orchard model from Kurtzman et al. (2013). Another model was constructed for water flow and nitrogen transport $\left(10 \mathrm{~kg} \mathrm{ha}^{-1} \mathrm{yr}^{-1}\right.$ nitrogen applied on ground surface) in the unsaturated zone below uncultivated areas using the hydraulic properties of the citrus orchard drill holes (this sampling point is at the center of the modeled area).

Thus, we created a "data library" of transient water and nitrate fluxes at the water table beneath the four land uses (posteriorly, the potato model was used for the vegetable land use because the strawberry deep fluxes were similar and the potato field covered a greater area). 


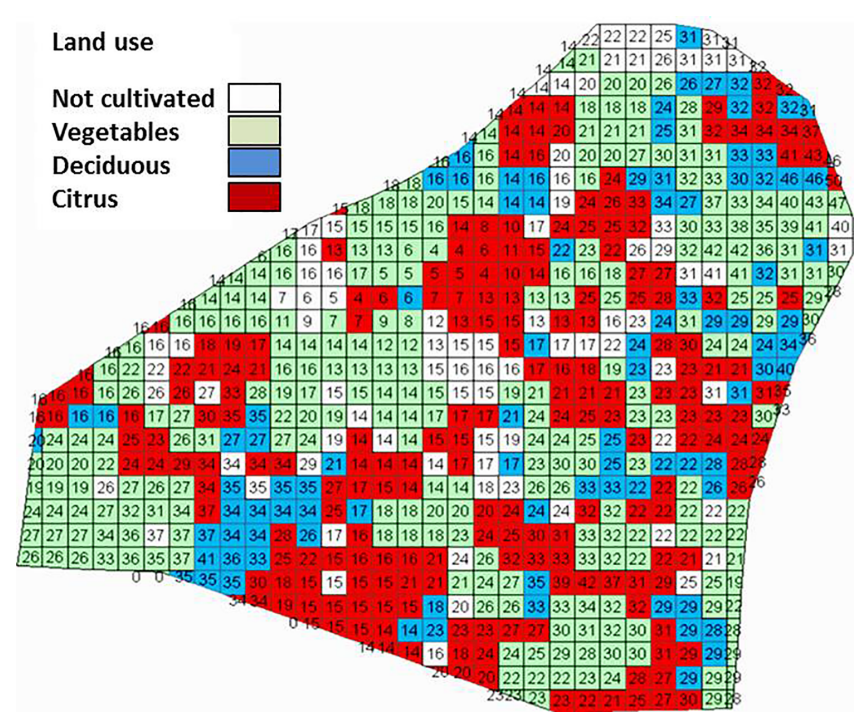

Figure 4. Land use (color) and depth to water table in meters (number) for each grid cell of the modeled area.

\subsection{Modeling of water flow and nitrate transport in the aquifer}

\subsubsection{Boundaries, data, spatial discretization, and simulation period}

A water flow and nitrate transport numerical model in the groundwater below the agricultural area in the Sharon region was developed. The model was constructed with GMS 8.2 software (AQUAVEO, 2012), the MODFLOW model for water flow (McDonald and Harbaugh, 1988), and the MT3D model for transport (Zheng, 1990). The model solves the water flow and advection-dispersion equations in the groundwater numerically (Eqs. 7 and 8):

$$
\begin{aligned}
& S_{\mathrm{S}} \cdot \frac{\partial h}{\partial t}=\frac{\partial}{\partial x}\left(K_{x x} \frac{\partial h}{\partial x}\right)+\frac{\partial}{\partial y}\left(K_{y y} \frac{\partial h}{\partial y}\right)+\frac{\partial}{\partial z}\left(K_{z z} \frac{\partial h}{\partial z}\right) \\
& \quad+R-P \\
& \frac{\partial C}{\partial t}=\frac{\partial}{\partial x}\left(D_{x} \frac{\partial C}{\partial x}\right)-\frac{\partial\left(v_{x} C\right)}{\partial x}+\frac{\partial}{\partial y}\left(D_{y} \frac{\partial C}{\partial y}\right)-\frac{\partial\left(v_{y} C\right)}{\partial y} \\
& \quad+\frac{\partial}{\partial z}\left(D_{z} \frac{\partial C}{\partial z}\right)-\frac{\partial\left(v_{z} C\right)}{\partial z}+\frac{R \cdot C_{\mathrm{duz}}}{n}-\frac{P \cdot C}{n}
\end{aligned}
$$

where $S_{\mathrm{S}}\left(\mathrm{L}^{-1}\right)$ is the specific storage, $h(\mathrm{~L})$ is the hydraulic head, $t(\mathrm{~T})$ is the time, $x, y, z(\mathrm{~L})$ are the threedimensional coordinates, $K_{x x}, K_{y y}$, and $K_{z z}\left(\mathrm{LT}^{-1}\right)$ are the hydraulic conductivities along the $x, y, z$ axes, $P$ and $R\left(\mathrm{~T}^{-1}\right)$ are volumetric fluxes per unit volume that represent sinks of water pumping in wells $(P)$ and sources of water from recharge $(R) . C\left(\mathrm{ML}^{-3}\right)$ is nitrate concentration in the aquifer, $D_{x}, D_{y}$, and $D_{z}\left(\mathrm{~L}^{2} \mathrm{~T}^{-1}\right)$ are hydrodynamic dispersion coefficients, $v_{x}, v_{y}$, and $v_{z}\left(\mathrm{LT}^{-1}\right)$ are the velocities, $n$ is porosity, and $C_{\mathrm{duz}}\left(\mathrm{M} \mathrm{L}^{-3}\right)$ is the nitrate concentration in the deep unsaturated zone (in the recharge flux). The last term on the right in Eq. (8) is the nitrate sink due to pumping.

The modeled area was a polygon of $13.3 \mathrm{~km}^{2}$ of agricultural land in the Sharon region of Israel. There has been no significant residential land use in this area in the last 60 years and all nitrate fluxes from the ground surface were assumed to be from agricultural sources. The boundary conditions were transient hydraulic heads and nitrate concentrations based on data from wells near the model boundaries. Model calibration was based on transient measured data in wells inside the polygon (Fig. 5a). Time series of well heads and nitrate concentrations for the boundary conditions and calibration were obtained from the Israel Water Authority.

The area was discretized to cells of $150: 150 \mathrm{~m}$. Vertically, the model consists of 13 layers with thicknesses set according to the wells' perforations (Fig. 5b and c). Each cell in the top layer is fed with specific transient fluxes of water and nitrate from the unsaturated zone, according to the unsaturatedzone land-use model and its thickness (Fig. 4).

The groundwater model was run for 20 years (19922012). The input source/sink fluxes and boundary conditions were inserted into the model as monthly values (stress period of 1 month). By choosing this period, we ensured that the fluxes from the unsaturated zone (model runs start in 1962) represent the land use and not an artifact of initial conditions of the unsaturated-zone models. Moreover, during the years 1992-2012, the average water level in the model regions was relatively stable (Israel Water Authority data), supporting the steady-state approximation of the unsaturated-zone thickness.

\subsubsection{Groundwater model calibration}

The water flow model was calibrated against measured water levels in the wells (1992-2012). The model was run with some zonation of horizontal hydraulic conductivity and a constant value of the storage coefficient until the mean absolute error (MAE) between measured and calculated water levels over the years was less than $0.5 \mathrm{~m}$, and the mean error (bias) was close to zero. Recharge fluxes from the unsaturated-zone models were strictly kept. In the first calibration stage of the nitrate transport model, dispersivity was fitted. Further steps in the calibration of this model were strongly related to the results and are elaborated upon in Sect. 3.

\subsubsection{Simulations of future nitrate contamination under various fertilization scenarios}

An approximation based on the unsaturated modeling results reported by Kurtzman et al. (2013) was used to estimate the nitrate fluxes at the water table under different fertilization scenarios: a decrease of $25 \%$ in the nitrogen-fertilization mass results in a decrease of $50 \%$ nitrate-nitrogen flux at the water table, whereas a reduction of $50 \%$ in nitrogen fertiliza- 
(a)

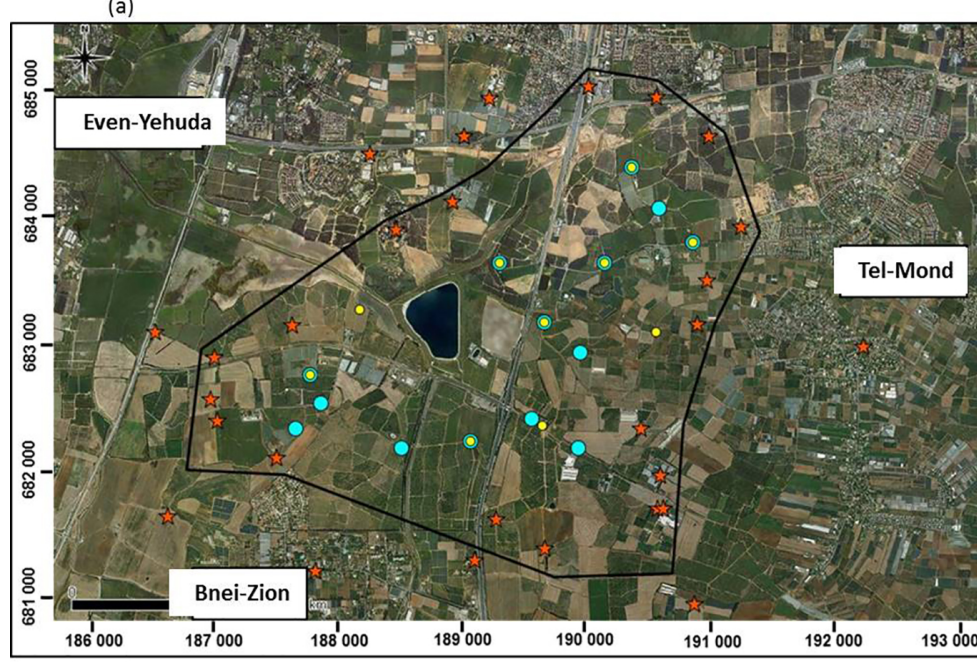

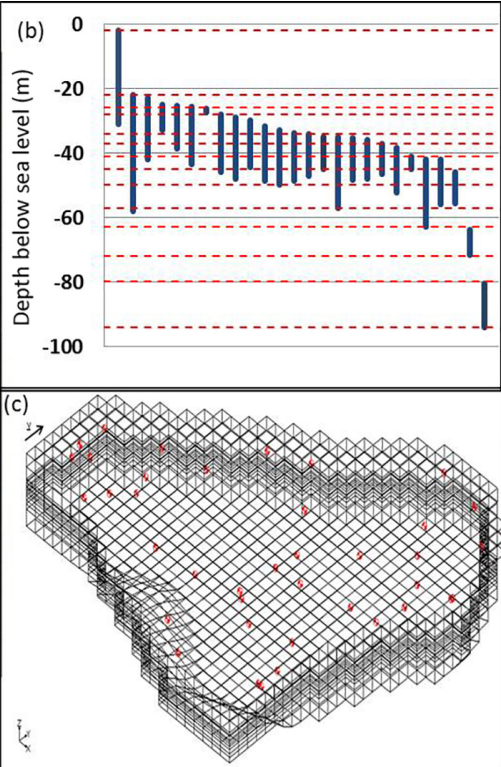

Figure 5. (a) Groundwater model boundaries and wells: red stars indicate well data used for transient boundary conditions; yellow spots indicate well data used for calibration of the flow model; blue spots indicate well data used for calibration of nitrate transport model. (b) Depth of well screens (blue vertical bars) and model layers (red horizontal dashed lines). (c) 3-D view of the model domain (finite difference discretization) and wells (red).

tion results in a $72 \%$ reduction in nitrate-nitrogen at the water table. Time series of nitrate-nitrogen fluxes at the water table were constructed using these ratios and the previously mentioned unsaturated flow and transport models (fitted to land uses and depth of the unsaturated zone). Three scenarios were tested: "business as usual", and 25 and $50 \%$ reduction in nitrogen application for the years 2012-2052. In these scenarios, it was assumed that land use would not change and that the precipitation and potential evapotranspiration would be the same as that of 1972 to 2012. In the groundwater transport model, the initial condition was the measured nitrate concentration in 2012. The transient nitrate-concentration boundary conditions were modified to account for similar reductions in nitrogen fertilization outside of the model domain. This was done in two steps: (1) running the model to the future with constant nitrate-concentration boundary conditions and looking at the trends of the nitrate concentration of the wells inside the model domain; (2) adjusting these trends to the boundary condition and running the model to the future again with transient nitrate-concentration boundary conditions.

\section{Results}

\subsection{Unsaturated zone}

\subsubsection{Sediment data and steady-state approximations of fluxes}

Some spatial variability within the plot of each land use was observed, with one extremely different nitrate profile under the persimmon orchard (Fig. 6). Steady-state recharge and nitrate-nitrogen fluxes (Eqs. 1 and 2) were calculated for the data from each core hole. The spatial variability seen in the profiles (Fig. 6) was reflected by the variable deep fluxes within the plots (Table 1). Transient models were constructed for one core hole in each field. Nitrate-nitrogen fluxes under the strawberry and potato fields were relatively simi$\operatorname{lar}\left(\sim 210 \mathrm{~kg} \mathrm{~N} \mathrm{ha}^{-1} \mathrm{yr}^{-1}\right)$; hence, the transient potato model that was calibrated to profile $\mathrm{C}$ was used for all areas of vegetable land use. The transient model representing the deciduous land use was Persimmon C (Table 1, Fig. 4). Hydraulically significant lithologic data of the sediment profiles as gravimetric percentage of the clay texture $(<0.002 \mathrm{~mm})$ are displayed in Table 2.

\subsubsection{Transient unsaturated-zone flow and nitrogen-transport models}

Table $2 \mathrm{a}-\mathrm{c}$ present the hydraulic, transport, and reaction model parameters that were calibrated to the observed unsaturated-zone data. The partition coefficient for ammo- 
Table 1. Average deep $(2-10 \mathrm{~m})$ porewater concentrations and steady-state approximations of water and nitrate-nitrogen fluxes calculated for each profile.

\begin{tabular}{lrrr|rrr|rrr}
\hline & \multicolumn{3}{c|}{ Potato } & \multicolumn{3}{c|}{ Strawberry } & \multicolumn{2}{c}{ Persimmon } \\
\cline { 2 - 9 } & A & B & C & A & B & C & A & B & C \\
\hline Pore water mean chloride concentration $\left(\mathrm{mg} \mathrm{L}^{-1}\right)$ & 421 & 192 & 266 & 198 & 179 & 188 & 234 & 232 & 263 \\
Pore water mean nitrate-nitrogen concentration $\left(\mathrm{mg} \mathrm{L}^{-1}\right)$ & 96 & 63 & 63 & 47 & 53 & 76 & 130 & 25 & 38 \\
Water recharge flux $\left(\mathrm{mm} \mathrm{yr}^{-1}\right)$ & 208 & 457 & 330 & 359 & 397 & 378 & 421 & 424 & 370 \\
Nitrate-nitrogen flux $\left(\mathrm{kg} \mathrm{ha}^{-1} \mathrm{yr}^{-1}\right)$ & 200 & 290 & 210 & 170 & 210 & 290 & 540 & 110 & 140 \\
\hline
\end{tabular}
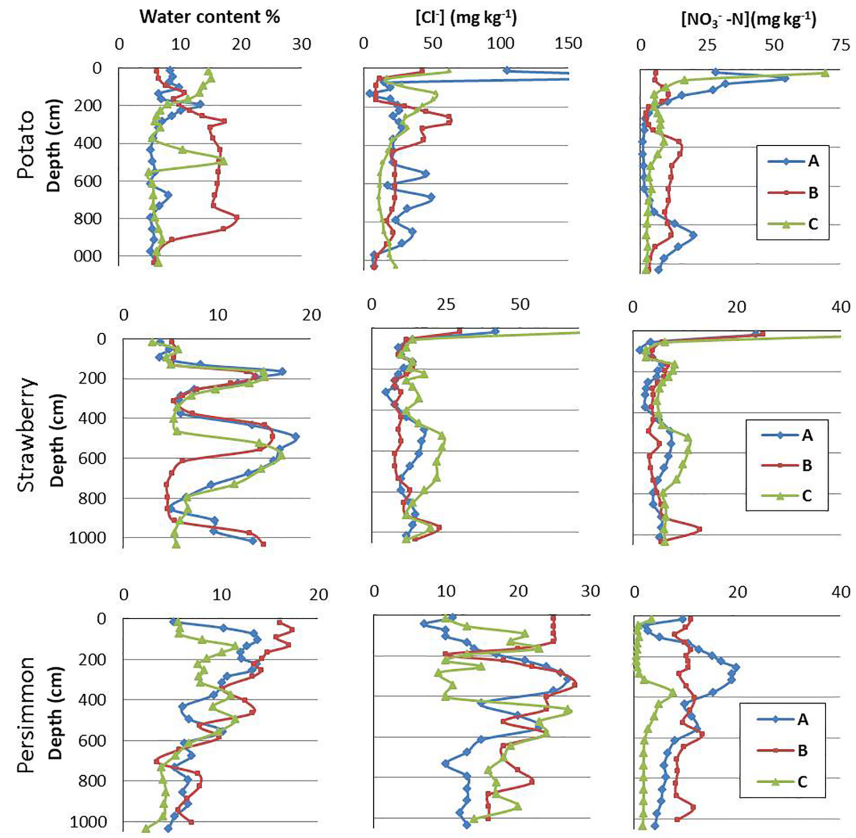

Figure 6. Gravimetric water content and concentrations of chloride and nitrate-nitrogen in the sediment profiles. There are three sampling core holes (A - blue, B - red, C - green) in each field (potato, strawberry, and persimmon).

nium, $k_{d-\mathrm{NH}_{4}}=3.5 \mathrm{~L} \mathrm{~kg}^{-1}$, was used in all layers, and the first-order mineralization rate was set to $\mu_{\min }=0.56$ day $^{-1}$ (Hanson et al., 2006). The relation of nitrate-nitrogen uptake to root-zone concentration and water uptake $\left(f_{\mathrm{NO}_{3}} \mathrm{SC}_{\mathrm{NO}_{3}}\right)$ was of the form used by Kurtzman et al. (2013) with limiting nitrate-nitrogen concentrations of 45,35 , and $20 \mathrm{mg} \mathrm{L}^{-1}$ for potato, strawberry, and persimmon, respectively. Limitation of the nitrogen reactions to the top layers of the soil was based on previous work in which nitrification potential was analyzed in orchard soils from this region (Kurtzman et al., 2013). Water and nitrogen balances resulting from the calibrated models showed significant recharge and deep nitratenitrogen leaching (40-55\% of total nitrogen input) under the investigated agricultural land (Table $3 a$ and $b$ ). The yearly average (for 2002-2012) water and nitrate-nitrogen fluxes toward the water table calculated by the numerical models and those calculated by the steady-state approximation (chloride mass balance) matched well (Table $3 a$ and $b$ ). The maximal difference between the two methods was $24 \mathrm{~mm} \mathrm{yr}^{-1}(6.5 \%)$ and $20 \mathrm{~kg} \mathrm{ha}^{-1} \mathrm{yr}^{-1}(7 \%)$ for the water and nitrate-nitrogen fluxes, respectively. The average flux of nitrate-nitrogen toward the water table in citrus orchards in this area was found to be $30 \%$ of the total nitrogen input (Kurtzman et al. 2013), lower than the leaching fraction under the vegetable and deciduous areas investigated here.

\subsection{Groundwater model}

\subsubsection{Model calibration}

The flow model was calibrated by assigning different horizontal hydraulic conductivities, in the range of $K_{x x}=K_{y y}=4.5-30 \mathrm{md}^{-1}$, to five subregions, where the higher values are in the western part of the modeled area. These hydraulic conductivity values are similar to previous studies in the Sharon region of the Israel coastal aquifer (Bachmat et al., 2003; Lutsky and Shalev, 2010). The calibrated anisotropy was $K_{x x} K_{z z}^{-1}=5$ and the specific yield was $S_{\mathrm{y}}=0.12$.

The goodness-of-fit parameters between calculated and observed heads were the MAE and the mean error (the bias), calculated for each observation well (Table 4) and for all observations. The improvement in the calibration ceased when the target weighted-average MAE less than $0.5 \mathrm{~m}$ and bias less than 0.1 for all observations were achieved (Table 4 , Fig. 7).

The nitrate transport model was calibrated by changing the dispersivity value, starting with a value in line with Neuman's (1990) formula. The final transport parameters used in the calibrated model were dispersivity of $500 \mathrm{~m}$, ratio between longitudinal and transverse dispersivities of 10 , and effective porosity of 0.12 . This first stage of the calibration resulted in a good fit between observed and modeled mean nitrate concentration for the entire modeled area (i.e., spatially weighted average with weights for each well calculated by the Thiessen polygon method; Thiessen, 1911). However, the model showed poor fits between observed and calculated nitrate concentrations at each well separately (Table 5, Fig. 8a). This means that the model reconstructed well the entire mass 
Table 2. Measured clay content and parameters of the calibrated unsaturated-zone flow and transport models under (a) potato field, (b) strawberry field, and (c) persimmon orchard. Note that in some layers hydraulic parameters were modified during calibrations (nd - no data).

\begin{tabular}{|c|c|c|c|c|c|c|c|c|c|c|c|c|}
\hline \multicolumn{13}{|l|}{ (a) } \\
\hline \multicolumn{10}{|c|}{ Flow and transport parameters } & \multirow{3}{*}{\multicolumn{3}{|c|}{$\begin{array}{c}\text { Reaction parameters } \\
\text { Volatilization }\left(\mathrm{NH}_{4}\right) \text {, nitrification, } \\
\text { denitrification }\end{array}$}} \\
\hline \multirow[t]{3}{*}{ Layer } & \multirow{3}{*}{$\begin{array}{l}\text { Depth } \\
\text { (m) }\end{array}$} & \multirow{3}{*}{$\begin{array}{r}\text { Clay } \\
(\%)\end{array}$} & \multicolumn{2}{|c|}{ Water content } & \multirow{3}{*}{$\begin{array}{r}\alpha \\
\left(\mathrm{cm}^{-1}\right)\end{array}$} & \multirow[t]{3}{*}{$n$} & \multirow{3}{*}{$\begin{array}{r}\text { Saturate hydraulic } \\
\text { conductivity K } \\
\left(\mathrm{cm} \mathrm{day}^{-1}\right)\end{array}$} & \multirow{3}{*}{$\begin{array}{r}\text { Bulk density } \rho \\
\left(\mathrm{gr} \mathrm{cm}^{-3}\right)\end{array}$} & \multirow{3}{*}{$\begin{array}{r}\text { Dispersivity } \\
(\mathrm{cm})\end{array}$} & & & \\
\hline & & & Residual $\theta \mathrm{r}$ & Saturation $\theta \mathrm{s}$ & & & & & & & & \\
\hline & & & & & & & & & & $\mu_{\mathrm{vol}}\left(\mathrm{day}^{-1}\right)$ & $\mu_{\text {nit }}\left(\right.$ day $\left.^{-1}\right)$ & $\mu_{\text {dnit }}\left(\right.$ day $\left.^{-1}\right)$ \\
\hline 1 & $0-0.15$ & 19 & 0.068 & 0.415 & 0.025 & 1.6 & 68 & 1.45 & 1.5 & 0.05 & 0.2 & 0.005 \\
\hline 2 & $0.15-0.3$ & 19 & 0.068 & 0.415 & 0.025 & 1.6 & 68 & 1.45 & 1.5 & 0 & 0.2 & 0 \\
\hline 3 & $0.3-0.45$ & 19 & 0.068 & 0.415 & 0.025 & 1.6 & 68 & 1.45 & 1.5 & 0 & 0.05 & 0 \\
\hline 4 & $0.45-1.5$ & nd & 0.058 & 0.420 & 0.031 & 3.1 & 675 & 1.45 & 10 & 0 & 0 & 0 \\
\hline 5 & $1.5-4$ & 11 & 0.065 & 0.445 & 0.028 & 1.8 & 165 & 1.46 & 25 & 0 & 0 & 0 \\
\hline 6 & $4-5.2$ & 4 & 0.057 & 0.409 & 0.031 & 3.3 & 775 & 1.43 & 12 & 0 & 0 & 0 \\
\hline 7 & $5.2-9.4$ & 5 & 0.057 & 0.406 & 0.031 & 3.3 & 766 & 1.6 & 38 & 0 & 0 & 0 \\
\hline 8 & $9.4-10.15$ & 2 & 0.068 & 0.415 & 0.025 & 1.6 & 68 & 1.57 & 9 & 0 & 0 & 0 \\
\hline 9 & $10.15-10.3$ & nd & 0.065 & 0.445 & 0.028 & 1.8 & 165 & 1.46 & 25 & 0 & 0 & 0 \\
\hline \multicolumn{13}{|l|}{ (b) } \\
\hline 1 & $0-0.15$ & 3 & 0.053 & 0.401 & 0.033 & 3.2 & 709 & 1.46 & 1.5 & 0.05 & 0.18 & 0.001 \\
\hline 2 & $0.15-0.3$ & 3 & 0.053 & 0.401 & 0.033 & 3.2 & 709 & 1.46 & 1.5 & 0 & 0.18 & 0.005 \\
\hline 3 & $0.3-0.45$ & 3 & 0.053 & 0.401 & 0.033 & 3.2 & 709 & 1.46 & 1.5 & 0 & 0.005 & 0 \\
\hline 4 & $0.45-1.5$ & 3 & 0.053 & 0.401 & 0.033 & 3.2 & 709 & 1.46 & 10.5 & 0 & 0 & 0 \\
\hline 5 & $1.5-2.9$ & 23 & 0.068 & 0.388 & 0.024 & 1.4 & 34 & 1.56 & 14 & 0 & 0 & 0 \\
\hline 6 & $2.9-4.95$ & 3 & 0.053 & 0.405 & 0.032 & 3.4 & 788 & 1.44 & 2 & 0 & 0 & 0 \\
\hline 7 & $4.95-6.15$ & 18 & 0.065 & 0.408 & 0.026 & 1.6 & 61 & 1.49 & 12 & 0 & 0 & 0 \\
\hline 8 & $6.15-7$ & 18 & 0.075 & 0.489 & 0.026 & 1.4 & 98 & 1.23 & 8.5 & 0 & 0 & 0 \\
\hline 9 & $7-7.65$ & 18 & 0.059 & 0.358 & 0.028 & 1.4 & 31 & 1.65 & 6.5 & 0 & 0 & 0 \\
\hline 10 & $7.65-10.3$ & 4 & 0.054 & 0.392 & 0.031 & 3.4 & 767 & 1.5 & 25 & 0 & 0 & 0 \\
\hline \multicolumn{13}{|l|}{ (c) } \\
\hline 1 & $0-0.15$ & 12 & 0.06 & 0.404 & 0.028 & 2 & 159 & 1.48 & 1.5 & 0.08 & 0.1 & 0.0025 \\
\hline 2 & $0.15-0.3$ & 12 & 0.06 & 0.404 & 0.028 & 2 & 159 & 1.48 & 1.5 & 0 & 0.01 & 0.001 \\
\hline 3 & $0.3-0.45$ & 12 & 0.06 & 0.404 & 0.028 & 2 & 159 & 1.48 & 7 & 0 & 0 & 0 \\
\hline 4 & $0.45-1.2$ & 12 & 0.06 & 0.404 & 0.028 & 2 & 159 & 1.48 & 20 & 0 & 0 & 0 \\
\hline 5 & $1.2-2.1$ & 15 & 0.059 & 0.367 & 0.028 & 1.6 & 60 & 1.61 & 9 & 0 & 0 & 0 \\
\hline 6 & $2.1-3.45$ & 12 & 0.056 & 0.364 & 0.030 & 1.9 & 114 & 1.61 & 13.5 & 0 & 0 & 0 \\
\hline 7 & $3.45-5.9$ & 11 & 0.055 & 0.353 & 0.030 & 1.7 & 62 & 1.65 & 24 & 0 & 0 & 0 \\
\hline 8 & $5.9-7.05$ & 4 & 0.057 & 0.392 & 0.030 & 3.1 & 599 & 1.49 & 12 & 0 & 0 & 0 \\
\hline 9 & $7.05-10.3$ & 2 & 0.053 & 0.353 & 0.030 & 4.5 & 1357 & 1.5 & 32 & 0 & 0 & 0 \\
\hline
\end{tabular}

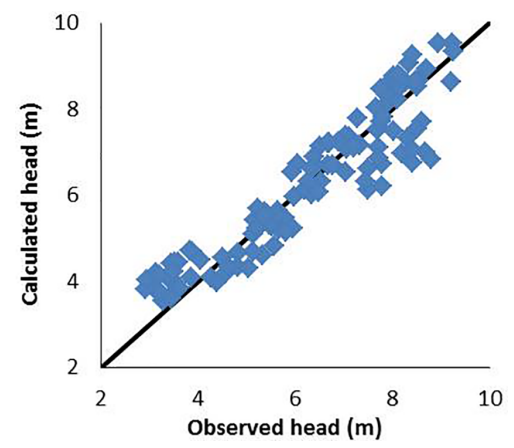

Figure 7. Calibrated flow model's calculated vs. observed heads in meters above mean sea level. The black line indicates where calculated values are equal to observed values.

of nitrate in the aquifer but it failed to describe nitrate's spatial variability (bottom two lines in Table 5a vs. observed, average, and standard deviations). To test whether the nitrate inputs from the unsaturated-zone model are significant in comparison to nitrate flowing from the boundaries (variableconcentration boundary condition), the model was run with zero nitrate flux from the unsaturated zone. The overall average nitrate concentration was 0.66 of the observed concentration (bottom two lines in Table 5b vs. observed, averages, and standard deviations). These results led to the understanding that although the unsaturated model produces good values for overall nitrate flux, the contaminated wells cannot be modeled with fluxes resulting from "normal" agricultural practice. The meaning of this is that nitrate spatial variability cannot be explained only by physical process of agricultural practice and land-use variability on surface. Other factors, that are local and arbitrary, significantly affect nitrate concentration in some wells and therefore the measured spatial variability of nitrate in the aquifer. These factors were introduced into the numerical model as will be explained hereafter.

Simulations showed that observed nitrate concentrations above $100 \mathrm{mg} \mathrm{L}^{-1}$ cannot be simulated with the nitrate fluxes produced by the calibrated unsaturated-zone model (Table $3 b)$. Multiplication of fluxes by up to a factor of 10 was needed to produce high concentrations in the wells. On the other hand, we had to maintain the overall flux of nitrate over the entire model domain. Therefore, in the second stage 
Table 3. Annual average (a) water and (b) nitrogen balance calculated by the unsaturated transient flow and transport models for 2002-2012, and comparison of deep fluxes to steady-state approximations. CMB indicates chloride mass balance.

\begin{tabular}{|c|c|c|c|c|}
\hline \multicolumn{2}{|l|}{ (a) } & \multirow{2}{*}{$\begin{array}{r}\text { Potato } \\
463\end{array}$} & \multirow{2}{*}{$\begin{array}{r}\text { Strawberry } \\
1050\end{array}$} & \multirow{2}{*}{$\begin{array}{r}\text { Persimmon } \\
822\end{array}$} \\
\hline Average water input $\left(\mathrm{mm} \mathrm{yr}^{-1}\right)$ & Irrigation & & & \\
\hline & Rain & 607 & 0 & 538 \\
\hline \multirow[t]{3}{*}{ Average water output $\left(\mathrm{mm} \mathrm{yr}^{-1}\right)$} & Root uptake & 467 & 367 & 639 \\
\hline & Evaporation & 276 & 335 & 352 \\
\hline & Recharge & 323 & 354 & 366 \\
\hline \multicolumn{2}{|c|}{ Recharge by CMB $\left(\mathrm{mm} \mathrm{yr}^{-1}\right.$; wells $\mathrm{C}$ in Table 1$)$} & 330 & 378 & 370 \\
\hline \multicolumn{5}{|l|}{ (b) } \\
\hline \multirow[t]{3}{*}{ Average nitrogen input $\left(\mathrm{kg} \mathrm{ha}^{-1} \mathrm{yr}^{-1}\right)$} & Fertilization & 450 & Mineral-350 & 200 \\
\hline & & & Organic-100 & \\
\hline & Nitrate-nitrogen in irrigation water & 50 & 100 & 90 \\
\hline \multirow[t]{5}{*}{ Average nitrogen output $\left(\mathrm{kg} \mathrm{ha}^{-1} \mathrm{yr}^{-1}\right)$} & Ammonia volatilization & 65 & 35 & 25 \\
\hline & Denitrification & 65 & 75 & 35 \\
\hline & Root ammonium-nitrogen uptake & 20 & 35 & 20 \\
\hline & Root nitrate-nitrogen uptake & 165 & 125 & 110 \\
\hline & Nitrate-nitrogen flux toward groundwater & 200 & 310 & 130 \\
\hline \multicolumn{2}{|c|}{$\begin{array}{l}\text { Nitrate-nitrogen flux toward groundwater by chloride mass balance } \\
\left(\mathrm{kg} \mathrm{ha}^{-1} \mathrm{yr}^{-1} \text {; wells } \mathrm{C} \text { in Table } 1\right)\end{array}$} & 210 & 290 & 140 \\
\hline \multicolumn{2}{|l|}{ Nitrate-nitrogen leaching percentage } & $40 \%$ & $55 \%$ & $45 \%$ \\
\hline
\end{tabular}
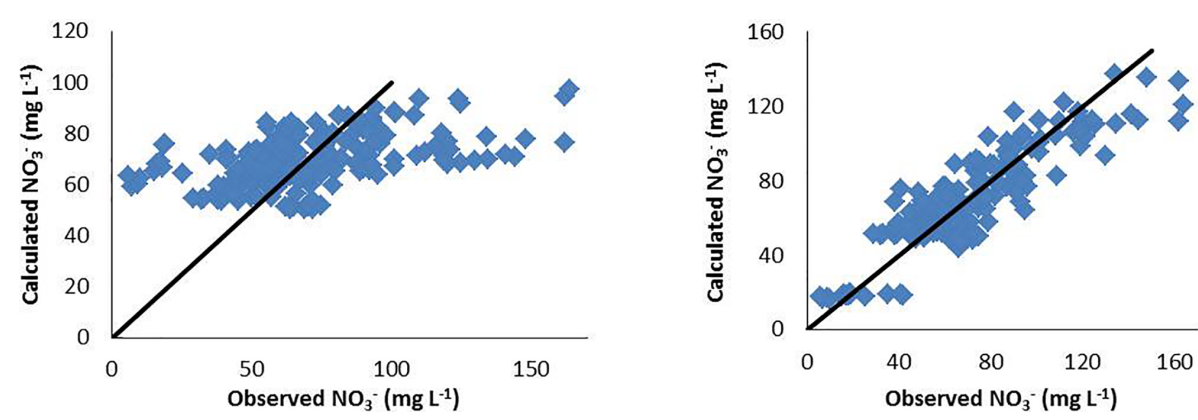

Figure 8. Calculated vs. observed nitrate concentrations: (a) after the first calibration stage (parameter fit); (b) after the second calibration stage (local multipliers). The black line indicates where calculated values are equal to observed values.

of the calibration, nitrate fluxes that were calculated by the unsaturated-zone model were multiplied by factors as follows: $1 \%$ of the area - factor of 10 (near the most contaminated wells); $3 \%$ of the area - factor of $5 ; 4 \%$ - factor of $2.8 ; 55 \%$ - factor of $1 ; 19 \%$ - factor of 0.6 , and in $18 \%$ of the area, the fluxes were multiplied by a factor of 0.1 . The reasoning and some physical explanations for these extreme fluxes in small areas surrounding some wells will be discussed later (in Sect. 4). These local multipliers resulted in a reasonable fit between observed and modeled nitrate concentrations for each well separately and the overall nitrate average and standard deviation (bottom two lines in Table $5 \mathrm{c}$ vs. observed).

\subsubsection{Simulations of three fertilization scenarios 40 years into the future}

The calibrated model was run to 40 years in the future (20122052) under three scenarios: (i) business as usual; (ii) application of $75 \%$ of the currently applied nitrogen fertilization; (iii) application of $50 \%$ of the currently applied nitrogen fertilization. The simulation results showed that (i) the average concentration in all wells in the simulated area will continue to increase in the business as usual scenario, reaching $106 \mathrm{mg} \mathrm{L}^{-1}$ in 2052 (vs. $87 \mathrm{mg} \mathrm{L}^{-1}$ in 2012); (ii) reducing the fertilization to $75 \%$ will approximately maintain the present concentrations; (iii) reducing the fertilization to $50 \%$ will lead to a trend of declining nitrate concentration to less than $70 \mathrm{mg} \mathrm{L}^{-1}$ (Israel's drinking water standard for nitrate) as an average for all wells in the modeled area (Fig. 9 and 
Table 4. Goodness of fit of the calibrated flow model (calculatedobserved). MAE - mean absolute error; bias - mean error.

\begin{tabular}{lrrr}
\hline Well Name & $\begin{array}{r}\text { No. of } \\
\text { observations }\end{array}$ & MAE (m) & Bias (m) \\
\hline Tel Mond Ziv A & 8 & 0.31 & 0.15 \\
Tel Mond 8 & 6 & 0.40 & 0.21 \\
Herut 41/3 & 20 & 0.48 & 0.29 \\
Tel Mond 13 & 9 & 0.25 & $<0.01$ \\
Bnei Dror D & 1 & 0.31 & -0.31 \\
Tel Izhak C & 18 & 0.34 & -0.31 \\
Tel Izhak 41/2 & 20 & 0.61 & 0.49 \\
Gan Efraim 3 & 27 & 0.72 & -0.56 \\
Gan Efraim 2 & 8 & 0.19 & 0.10 \\
Gan Shlomo Berman-Cohen & 6 & 0.45 & 0.45 \\
\hline Total observations and & 123 & 0.48 & $<0.01$ \\
weighted-average errors & & & \\
\hline
\end{tabular}

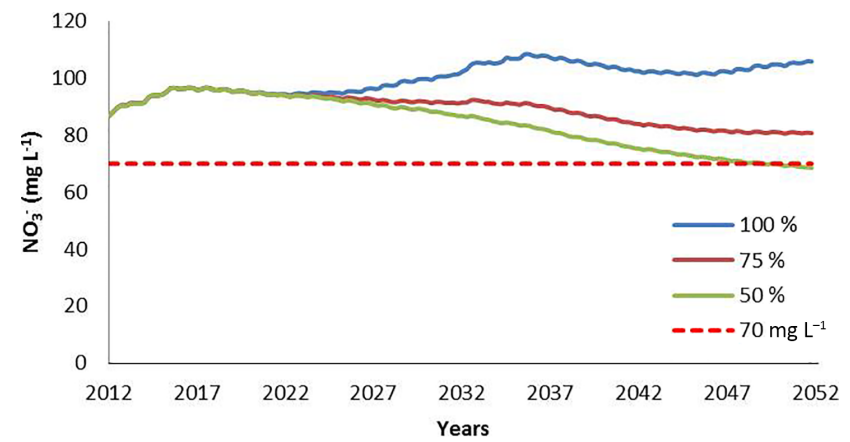

Figure 9. Simulations of future average nitrate concentrations in wells under three nitrogen-fertilization scenarios: 100, 75 and $50 \%$ of the current application used by farmers. Israel's drinking water standard for nitrate is $70 \mathrm{mg} \mathrm{L}^{-1}$.

Table 6). Even in this case about half of the wells will still exceed the standard concentration.

\section{Discussion}

Our results showed successful evaluation of the total mass of nitrate in the aquifer using data of agricultural practice and deep unsaturated-zone samples to calibrate flow and transport models of the unsaturated zone which feed the aquifer. Nevertheless, this straightforward model failed to produce the observed spatial variability of nitrate concentrations in wells, which required a random non-mechanistic modeling approach.

Successful delivery of the total volumes of water and nitrate mass to the $13.3 \mathrm{~km}^{2}$ aquifer under agricultural land was achieved despite the following first-order assumptions: only four types of land use (three crops); steady crops for 50 years; homogeneity of agricultural practices and similar profiles of porous medium within each crop. These assumptions neglect small-scale variability yet work for the regional-scale totals

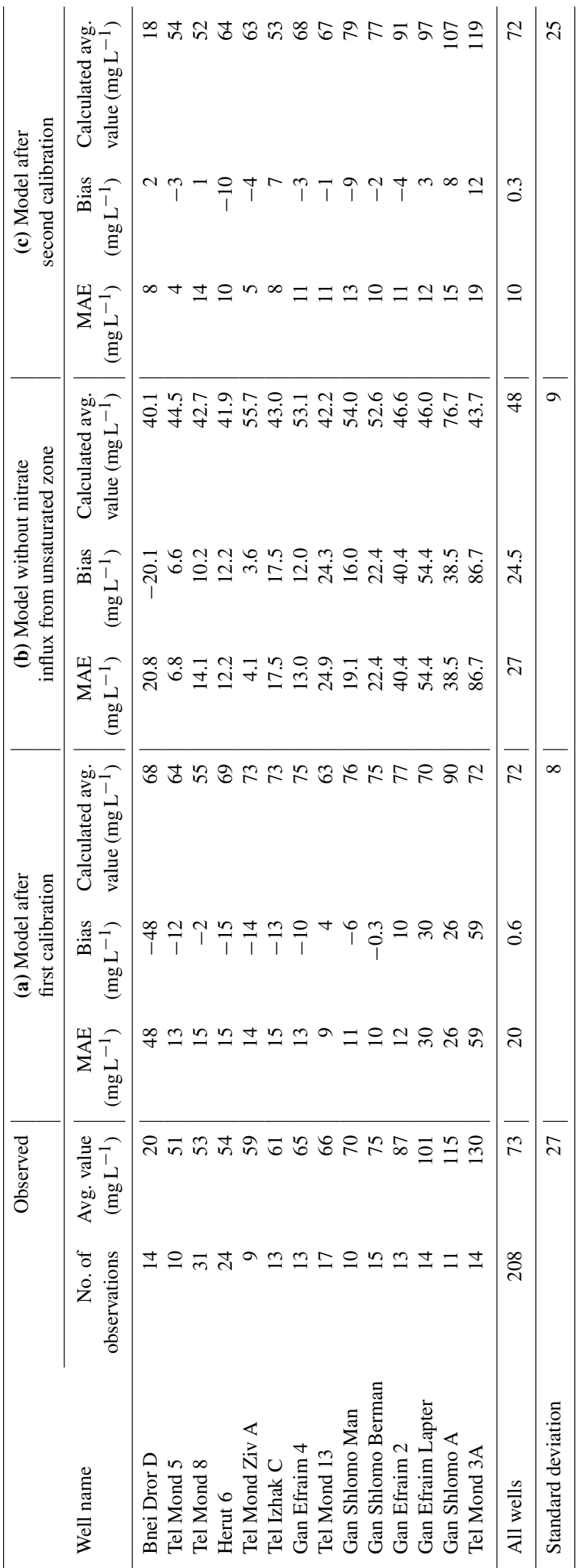


for the following reasons: the farmers generally follow irrigation and fertilization recommendations made by extension services; about half of the land is covered by orchards for which applications of water and fertilizer have been steady for decades; on a regional scale, if the soil properties are generally similar, the details of the different profiles of the deep unsaturated zone have only a minor effect.

Failure to reproduce the spatial variability of nitrate concentrations lies mainly in predicting the extreme concentrations in some wells. These nitrate concentrations cannot be explained by any rational agricultural practice and are a result of random failure of even fertilizer distribution in the field that can be due to one or more of the following reasons. It should be acknowledged that water wells are often at the "logistic center" of the agricultural field, and organic and mineral fertilizers are stocked nearby; temporal leakage can cause high concentrations in the well for years afterwards. Furthermore, the immediate area of the well is susceptible to preferential flow paths due to incidental ponding (Gurdak et al., 2008) and/or shortcuts through the annulus of the boreholes. This is especially common in old private boreholes that are used mainly for irrigation, which are common in the investigated area. Heterogeneity of the porous medium may cause extremely high nitrate fluxes as well as well failure discussed previously and may be a source for local high contamination. The field survey reported here supports this statement. Of the nine deep profiles reported here (Fig. 6, Table 1), one showed extreme nitrate concentrations and calculated nitrate fluxes that were 4- to 5-fold higher than in the other profiles extracted from the same orchard (Persimmon A, Table 1). Multipliers that adjust nitrate fluxes to groundwater were used in models previously (e.g., Alikhani et al., 2016). The 2 orders of magnitude difference in nitrate multipliers (0.1-10) used in this work is not incomparable; Kourakos et al. (2012) used distributions with means of 1 to $100 \mathrm{~m} \mathrm{~L} \mathrm{~L}^{-1}$ nitrate loading to groundwater for the same land use. Therefore, the heuristic multiplications used to calibrate the nitrate transport model were ultimately justified. Moreover, these multiplications were essential for simulating future scenarios (Fig. 9, Table 6).

The workflow in this study did not include model validation after each calibration stage (i.e., for each land use unsaturated: flow, conservative transport, and nitrogen reactive transport; groundwater flow and groundwater transport), which is of course a disadvantage. Validation tests for each calibration would have given a statistical measure of the goodness of fit of the calibrated model with independent (left out of calibration) observations, rather than only the calibration fit. Nonetheless, the conclusions of this work are highly significant because they are based on entirely independent data. The total mass of nitrate that crossed the water table (unsaturated-zone models) is verified by the groundwater well data, whereas the failure to reproduce the spatial variability would have not been changed with validation fit estimates.
Table 6. Current (2012) observed nitrate concentrations and those simulated for the year 2052 for three nitrogen-fertilization scenarios: 100,75 , and $50 \%$ of the current application used by farmers. Bold values indicate concentrations below the Israeli drinking water standard for nitrate.

\begin{tabular}{lrrrr}
\hline Well name & $\begin{array}{r}\text { Observed } \\
\left(2012, \mathrm{mg} \mathrm{L}^{-1}\right)\end{array}$ & $\begin{array}{r}\text { Simulated concentrations } \\
\text { at } 2052\left(\mathrm{mg} \mathrm{L}^{-1}\right) \\
\text { for fertilization scenario }\end{array}$ \\
\cline { 2 - 5 } & & $100 \%$ & $75 \%$ & $50 \%$ \\
\hline Bnei Dror D & $\mathbf{1 6}$ & $\mathbf{2 7}$ & $\mathbf{2 1}$ & $\mathbf{1 9}$ \\
Tel Mond 5 & $\mathbf{6 0}$ & 77 & $\mathbf{6 4}$ & $\mathbf{5 7}$ \\
Tel Mond 8 & $\mathbf{6 0}$ & 82 & $\mathbf{6 8}$ & $\mathbf{6 1}$ \\
Herut 6 & $\mathbf{6 9}$ & 79 & $\mathbf{6 7}$ & $\mathbf{6 0}$ \\
Tel Mond Ziv A & $\mathbf{7 0}$ & 83 & $\mathbf{6 8}$ & $\mathbf{5 9}$ \\
Tel Izhak C & 73 & 96 & 73 & $\mathbf{6 2}$ \\
Gan Efraim 4 & 79 & 101 & 77 & $\mathbf{6 6}$ \\
Tel Mond 13 & 78 & 99 & 80 & 71 \\
Gan Shlomo Man & 88 & 107 & 84 & 73 \\
Gan Shlomo Berman-Cohen & 90 & 109 & 86 & 75 \\
Gan Efraim 2 & 106 & 138 & 101 & 84 \\
Gan Efraim Lapter & 122 & 139 & 98 & 78 \\
Gan Shlomo A & 128 & 130 & 103 & 89 \\
Gan Efraim 3 & 129 & 157 & 108 & 86 \\
Tel Mond 3A & 134 & 164 & 112 & 88 \\
\hline Average & 87 & 106 & 81 & $\mathbf{6 9}$ \\
Standard deviation & 26.7 & 29.1 & 16.5 & 11.5 \\
\hline
\end{tabular}

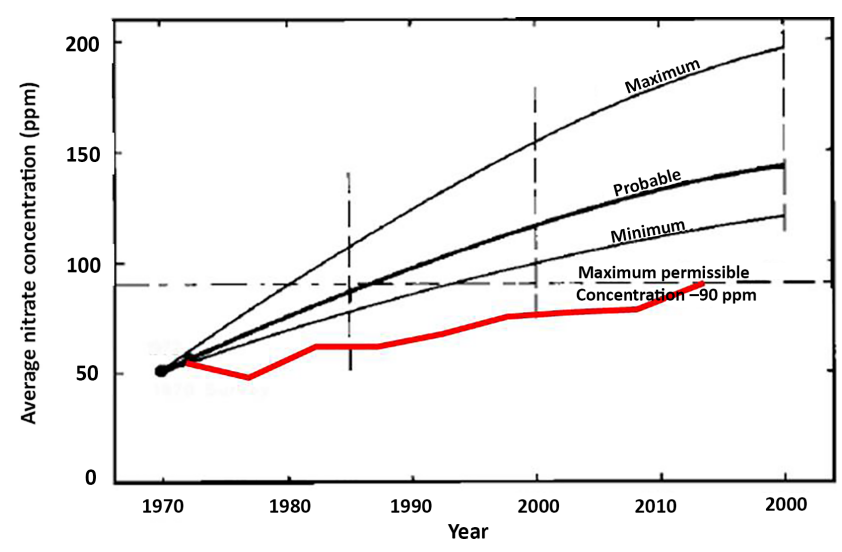

Figure 10. Post-audit of average nitrate concentration predicted in 1976 for another part of the Israeli coastal aquifer. All black lines and writing are original predictions from Mercado (1976). The red line indicates the historical average nitrate concentrations from the wells in that area that were produced since 1970 (no new wells; data were obtained from the Israel Water Authority). The maximum permissible concentration of nitrate was reduced from 90 to $70 \mathrm{mg} \mathrm{L}^{-1}$ in 2001 .

In the case of the Israeli coastal aquifer, we are fortunate enough to be able to perform a post-audit analysis of nitrate-level predictions made 40 years ago in another part of the aquifer (Rehovot-Rishon region, Fig. 1). This region of the aquifer was overlain mainly by agricultural land (in 1950-1970) with similar sandy-loam (Hamra) soils (Mercado, 1976). The latter work predicted a continual increase in nitrate concentration in the groundwater below this area, 
from $50 \mathrm{mg} \mathrm{L}^{-1}$ in 1970 to a range of $120-180 \mathrm{mg} \mathrm{L}^{-1}$ in 2015 (Fig. 10). The observed average concentration in this area in 2014 was $90 \mathrm{mg} \mathrm{L}^{-1}$ (Israel Water Authority data). This is indeed an increase but not the expected one. On the other hand, this increase of $40 \mathrm{mg} \mathrm{L}^{-1}$ over 45 years is similar to the nitrate concentration increase in the Sharon area (Kurtzman et al., 2013).

The main reason for the overshoot of Mercado's (1976) prediction is probably the very significant reduction in agricultural land due to urbanization in this area in the last 5 decades. Most of this urbanization is agricultural towns which became modern cities with tight sewage systems, where practically all the wastewater is piped to treatment plants. In the current work, the predictions were also made assuming steady agricultural land use with no urbanization processes that might lead to a similar overshoot in nitrate concentration predictions.

\section{Summary and Conclusions}

Groundwater under irrigated agricultural land over light soils commonly suffers from nitrate contamination. Nevertheless, significant spatial variability in nitrate concentrations in these parts of the aquifer exist, suggesting that it is caused by variability in nitrate fluxes from the unsaturated zone. An agricultural area $\left(13.3 \mathrm{~km}^{2}\right)$ in the Sharon region overlying the Israeli coastal aquifer in which the abovementioned phenomena are observed was selected to investigate the process through calibrated flow and nitrate transport models from the agricultural land surface to the well screens (15 to $130 \mathrm{~m}$ below the surface). Unsaturated flow and nitrogen species transport models were calibrated to data from below the root zone that were obtained with direct push sampling under four typical crops in the area: citrus, persimmon, potato, and strawberry. The flow and nitrate transport model in the aquifer was fed from water and nitrate fluxes from the unsaturated models, and calibrated to water levels and nitrate concentrations in the wells. The agricultural data and the flow and transport models of the unsaturated zone successfully predicted the total mass of nitrate in the aquifer. However, they failed to predict the spatial variability of nitrate in the wells, which was observed to be significantly larger than predicted. Therefore, the solution for calibrating the nitrate transport model was to multiply the modeled nitrate fluxes at the water table in small areas around the most contaminated wells with high multipliers (2.8-10), whereas nitrate fluxes in larger areas around the non-contaminated wells were multiplied by low factors $(0.1-0.6)$, and in most of the area $(55 \%)$ the modeled fluxes from the unsaturated zone were conserved. The calibrated flow and transport model was then used to predict the development of nitrate concentrations in the aquifer 40 years in the future, with three nitratefertilization scenarios: business as usual (continuing present practice), or reducing nitrogen inputs by 25 or $50 \%$. None of the scenarios showed any improvement in aquifer conditions in the next 10 years. Reducing nitrate application by $50 \%$ will bring the average nitrate concentration in the aquifer to below drinking water standards in 40 years, whereas a cut of $25 \%$ will only bring it back to the current level in 40 years. We conclude that the total mass of nitrate in an aquifer under agricultural land can be calculated with significant success from relatively limited land-use and deep unsaturated-zone data. Nevertheless, highly contaminated wells are most probably effected by malfunction in the close vicinity of the well that cannot be predicted by a straightforward agrohydrological modeling scheme. Locally, it was shown that remediation of the aquifer on a half-century timescale requires reduction of the nitrogen-fertilization input in the range of $25-50 \%$.

Data availability. The unsaturated-zone data (0-10 m depth) are available via e-mail from the first author, Yehuda Levy, at yehuda.levy1@mail.huji.ac.il. Aquifer data are available from the Israel Water Authority (IWA, 2017) in accordance with the Israeli Freedom of Information Law 1998 (http://www.water.gov.il/ Hebrew/MoreInformation/Pages/Freedom-of-Information.aspx).

Competing interests. The authors declare that they have no conflict of interest.

Acknowledgements. The research leading to these results received funding from the Israeli Water Authority under research contract no. 4500571791 as well as from the Chief Scientist, Ministry of Agriculture, under contract nos. 304-0431-09 and 20-13-2013. Research was performed at the Agricultural Research Organization, Volcani Center.

Edited by: Marnik Vanclooster

Reviewed by: two anonymous referees

\section{References}

Alikhani, J., Deinhart, A. L., Visser, A., Bibby, R. K., Purtschert, R., Moran, J. E., Massoudieh, A., and Esser, B. K.: Nitrate vulnerability projections from Bayesian inference of multiple groundwater age tracers, J. Hydrol., 543, 167-181, 2016.

Allen, R. G., Pereira, L. A., Raes, D., and Smith, M.: Crop evapotranspiration, FAO irrigation and drainage paper 56, 15 pp., 1998.

Allison, G. B. and Hughes, M. W.: The use of natural tracers as indicators of soil-water movement in a temperate semi-arid region, J. Hydrol., 60, 157-173, https://doi.org/10.1016/00221694(83)90019-7, 1983.

Almasri, M. N. and Kaluarachchi, J.: Modeling nitrate contamination of groundwater in agricultural watersheds, J. Hydrol., 343 , 211-229, 2007.

AQUAVEO: The Department of Defense Groundwater Modeling System, GMS v8.2 Aquaveo, South Jordan, UT, 2012. 
Bachmat, Y., Daks, A., and Reshef, G.: Annual operations of the coastal aquifer of Israel, Hydrological Survey, Israel Water Authority, Jerusalem, Israel, 2003.

Bar-Yosef, B., Sagiv, B., and Fang, S.: Long-term effects of nitrogen fertilizers on crops and on nitrogen and salt balances in the soil, in unchanged fields, Gilat, Negev, Agric. Res. Israel J., 10, 3154, 1999 (in Hebrew).

Ben Hagai, N., Bruner, M., Raviv, M., Vulcan, R., Shoshani, B., and Eisenkot, A.: Characterization of organic materials for agriculture, Alon Hanotea, 16, 16-20, 2011 (in Hebrew).

Bian, J., Liu, C., Zhang, Z., Wang, R., and Gao, Y.: Hydrogeochemical characteristics and health risk evaluation of nitrate in groundwater, Polish J. Environ. Studies, 25, 521-527, https://doi.org/10.15244/pjoes/61113, 2016.

Burow, K. R., Nolan, B. T., Rupert, M. G., and Dubrovsky, N. M.: Nitrate in groundwater of the United States, 1991-2003, Environ. Sci. Technol., 44, 4988-4997, 2010.

Dahan, O., Babad, A., Lazarovitch, N., Russak, E. E., and Kurtzman, D.: Nitrate leaching from intensive organic farms to groundwater, Hydrol. Earth Syst. Sci., 18, 333-341, https://doi.org/10.5194/hess-18-333-2014, 2014.

de Paz, J. M. and Ramos, C.: Simulation of nitrate leaching for different nitrogen fertilization rates in region of Valencia (Spain) using a GIS-GLEAMS system, Agr. Ecosyst. Environ., 103, 5973, 2004.

Doltra, J. and Muñoz, P.: Simulation of nitrogen leaching from a fertigated crop rotation in a Mediterranean climate using the EU_Rotate_N and HYDRUS-2D models, Agr. Water Manage., 97, 277-285, 2010.

Eghball, B., Wienhold, B. J., Gilley, J. E., and Eigenberg, R. E.: Mineralization of manure nutrients. J. Soil Water Conserv., 57, 470-473, 2002.

Erisman, J. W., Sutton, M. A., Galloway, J., Zbigniew, K., and Wilfried, W.: How a century of ammonia synthesis changed the world, Nat. Geosci., 1, 636-639, 2008.

Feddes, R. A., Kowalik, P. J., and Zaradny, H.: Simulation of Field Water Use and Crop Yield, John Wiley \& Sons, New York, 1978.

Galloway, J. N., Dentener, F. J., Capone, D. G., Boyer, E. W., Howarth, R. W., Seitzinger, S. P., Asner, G. P., Cleveland, C. C., Green, P. A., Holland, E. A., Karl, D. M., Michaels, A. F., Porter J. H., Townsend, A. R., and Vöosmarty, C. J.: Nitrogen cycles: past, present, and future, Biogeochemistry, 70, 153-226, 2004.

Green, C. T., Jurgens, B. C., Zhang, Y., Starn, J. J., Singleton, M. J., Esser B. K.: Regional oxygen reduction and denitrification rates in groundwater from multi-model residence time distributions, San Joaquin Valley, USA, J. Hydrol., 543, 155-166, 2016.

Guimerá, J., Marfá, O., Candela, L., and Serrano, L.: Nitrate leaching and strawberry production under drip irrigation management, Agr. Ecosyst. Environ., 56, 121-135, 1995.

Gurdak, J. J., Walvoord, M. A., and McMahon, P. B.: Susceptibility to enhanced chemical migration from depression-focused preferential flow, High Plains Aquifer, Vadose Zone J., 7, 1172-1184, 2008.

Gvirtzman, H.: Israel Water Resources, Yad Ben-Zvi Press, Jerusalem, Israel, 2002 (in Hebrew).

Hanson, B. R., Šimůnek, J., and Hopmans, J. W.: Evaluation of urea-ammonium-nitrate fertigation with drip irrigation using numerical modeling, Agr. Water Manage., 86, 102-113, 2006.
Hu, K., Huang, Y., Li, H., Li, B., Chen, D., and White, R. E.: Spatial variability of shallow groundwater level, electrical conductivity and nitrate concentration, and risk assessment of nitrate contamination in North China Plain, Environ. Int., 31, 896-903, 2005.

IWA: Wastewater \& effluents in Israel, monitoring and prevention of water pollution, Israel Water Authority, available at: http://www.water.gov.il/Hebrew/ProfessionalInfoAndData/2012/ (last access: 23 July 2017), 2015a.

IWA: Development and utilization of water resources situation in Israel until the autumn of 2013, Israel Water Authority, available at: http://www.water.gov.il/Hebrew/ProfessionalInfoAndData/ Data-Hidrologeime/Pages/water-resources-2013.aspx (last access: 23 July 2017), 2015b (in Hebrew).

IWA: Freedom of information, available at: http://www.water.gov. il/Hebrew/MoreInformation/Pages/Freedom-of-Information. aspx, last access: 25 July 2017 (in Hebrew).

Jalali, M.: Nitrates leaching from agricultural land in Hamadan, western Iran, Agr. Ecosyst. Environ., 110, 210-218, 2005.

Ju, X. T., Kou, C. L., Zhang, F. S., and Christie, P.: Nitrogen balance and groundwater nitrate contamination: comparison among three intensive cropping systems on the North China Plain, Environ. Pollut., 143, 117-125, 2006.

Kachurina, O. M., Zhang, H., Raun, W. R., and Krenzer, E. G.: Simultaneous determination of soil aluminum, ammonium- and nitrate-nitrogen using $1 \mathrm{M}$ potassium chloride extraction, Commun. Soil Sci. Plant, 31, 893-903, 2000.

Kourakos, G., Klein, F., Cortis, A., and Harter, T.: A groundwater nonpoint source pollution modeling framework to evaluate longterm dynamics of pollutant exceedance probabilities in wells and other discharge locations, Water Resour. Res., 48, W00L13, https://doi.org/10.1029/2011WR010813, 2012.

Kraft, G. J. and Stites, W.: Nitrate impacts on groundwater from irrigated-vegetable systems in a humid north-central US sand plain, Agr. Ecosyst. Environ., 100, 63-74, 2003.

Kurtzman, D., Netzer, L., Weisbrod, N., Nasser, A., Graber, E. R., and Ronen, D.: Characterization of deep aquifer dynamics using principal component analysis of sequential multilevel data, Hydrol. Earth Syst. Sci., 16, 761-771, https://doi.org/10.5194/hess16-761-2012, 2012.

Kurtzman, D., Shapira, R. H., Bar-Tal, A., Fine, P., and Russo, D.: Nitrate fluxes to groundwater under citrus orchards in a Mediterranean climate: observations, calibrated models, simulations and agro-hydrological conclusions, J. Contam. Hydrol., 151, 93-104, 2013.

Kurtzman, D., Baram, S., and Dahan, O.: Soil-aquifer phenomena affecting groundwater under vertisols: a review, Hydrol. Earth Syst. Sci., 20, 1-12, https://doi.org/10.5194/hess-20-12016, 2016.

Levy, Y.: Observations and modeling of nitrate fluxes to groundwater under diverse agricultural land-uses: from the fields to the pumping wells, MS thesis, The Hebrew University of Jerusalem, Jerusalem, Israel, 2015.

Liao, L., Green, C. T., Bekins, B. A., and Böhlke, J. K.: Factors controlling nitrate fluxes in groundwater in agricultural areas, Water Resour. Res., 48, W00L09, https://doi.org/10.1029/2011WR011008, 2012.

Liu, G. D., Wu, W. L., and Zhang, J.: Regional differentiation of non-point source pollution of agriculture-derived nitrate nitrogen 
in groundwater in northern China, Agr. Ecosyst. Environ., 107, 211-220, 2005

Lutsky, H. and Shalev, E.: Slug tests for measuring the hydraulic conductivity and wells intactness in the coastal aquifer of Israel, Geological Survey of Israel, Jerusalem, Israel, 2010 (in Hebrew).

McDonald, M. G. and Harbaugh, A. W.: A modular threedimensional finite-difference ground-water flow model, US Geological Survey, US Government Printing Office, Washington DC, 1988.

McMahon, G. and Woodside, M. D.: Nutrient mass balance for the Albemarle-Palmico drainage basin, North Carolina and Virginia, 1990, J. Am. Water Resour. Ass., 33, 573-589, 1997.

Mercado, A.: Nitrate and chloride pollution of aquifers: a regional study with the aid of a single-cell model, Water Resour. Res., 12, 731-747, 1976.

Mualem, Y.: A new model for predicting the hydraulic conductivity of unsaturated porous media, Water Resour. Res., 12, 513-522, 1976.

Neilsen, D. and Neilsen, G. H.: Efficiency use of nitrogen and water in high-density apple orchards, HorTechnology, 12, 19-25, 2002.

Neuman, S. P.: Universal scaling of hydraulic conductivities and dispersivities in geologic media, Water Resour. Res., 26, 1749$1758,1990$.

Scanlon, B. R., Reedy, R. C., and Tachovsky, J. A.: Semiarid unsaturated zone chloride profiles: archives of past land use change impacts on water resources in the southern High Plains, United States, Water Resour. Res., 43, W064239, https://doi.org/10.1029/2006WR005769, 2007.

Schaap, M. G., Leij, F. J., and van Genuchten, M. T.: Rosetta: a computer program for estimating soil hydraulic parameters with hierarchical pedotransfer functions, J. Hydrol., 251, 163-176, 2001.

Šimůnek, J., Šejna, M., Saito, H., Sakai, M., and van Genuchten, M. Th.: The HYDRUS-1D software package for simulating the one-dimensional movement of water, heat, and multiple solutes in variably-saturated media, Riverside, CA, 2009.

Smil, V.: Detonator of the population explosion, Nature, 400, p. 415, https://doi.org/10.1038/22672, 1999.

Sorgona, A., Abenavoli, M. R., Gringeri, P. G., and Cacco, G.: A comparison of nitrogen use efficiency definitions in citrus rootstocks, Sci. Hort., 109, 389-393, 2006.

Spalding, R. F. and Exner, M. E.: Occurrence of nitrate in groundwater - A review, J. Environ. Qual., 22, 392-402, 1993.
Thayalakumaran, T., Lenahan, M. J., and Bristow, K. L.: Dissolved organic carbon in groundwater overlain by irrigated sugarcane, Groundwater, 53, 525-530, 2015.

Thiessen, A. H.: Precipitation for large areas, Mon. Weather Rev., 39, 1082-1084, 1911.

Turkeltaub, T., Kurtzman, D., Russak, E. E., and Dahan, O.: Impact of switching crop type on water and solute fluxes in deep vadose zone, Water Resour. Res., 51, 9828-9842, https://doi.org/10.1002/2015WR017612, 2015.

van Genuchten, M. T.: A closed-form equation for predicting the hydraulic conductivity of unsaturated soils, Soil Sci. Soc. Am J., 44, 892-898, 1980.

Venterea, R. T., Hyatt, C. R., and Rosen, C. J.: Fertilizer management effects on nitrate leaching and indirect nitrous oxide emissions in irrigated potato production, J. Environ. Qual., 40, 11031112, 2011.

Vitousek, P. M., Naylor, R., Crews, T., David, M. B., Drinkwater, L. E., Holland, E., Johnes, P. J., Katzenberger, J., Martinelli, L. A., Matson, P. A., Nziguheba, G., Ojima, D., Palm, C. A., Robertson, G. P., Sanchez, P. A., Townsend, A. R., and Zhang, F. S.: Nutrient imbalances in agricultural development, Science, 324 1519-1520, 2009.

Wang, L., Stuart, M. E., Lewis, M. A., Ward, R. S., Skirvin, D., Naden, P. S., Collins, A. L., and Ascott, M. J.: The changing trend in nitrate concentrations in major aquifers due to historical nitrate loading from agricultural land across England and Wales from 1925 to 2150, Sci. Total Environ., 542, 694-705, 2016.

Wheeler, D. C., Nolan, B. T., Flory, A. R., Dellavelle, C. T., and Ward, M. H.: Modeling groundwater nitrate concentrations in private wells in Iowa, Sci. Total Environ., 536, 481-488, 2015.

Yue, F. J., Liu, C. Q., Li, S. L., Zhao, Z. Q., Liu, X. L., Ding, H., Liu, B. J., and Zhong, J.: Analysis of $\delta^{15} \mathrm{~N}$ and $\delta^{18} \mathrm{O}$ to identify nitrate sources and transformations in Songhua River, Northeast China, J. Hydrol., 519, 329-339, 2014.

Zhao, B. Q., Li, X. Y., Liu, H., Wang, B. R., Zhu, P., Huang, S. M., Bao, D. J., Li, Y. T., and So, H. B.: Results from long-term fertilizer experiments in China: the risk of groundwater pollution by nitrate. Wageningen, J. Life Sci., 58, 177-183, 2011.

Zheng, C.: A Modular Three-Dimensional Transport Model for Simulation of Advection, Dispersion and Chemical Reaction of Contaminants in Groundwater Systems, S.S. Papadopulos \& Associates, Inc., Rockville, MD, 1990. 